\title{
Clinical presentation of health care workers with symptoms of coronavirus disease 2019 at the İzmir tertiary education hospital, during an early phase of the pandemic
}

\author{
Filiz GÜLDAVAL ${ }^{1}$ (ID) \\ Ceyda $\operatorname{ANAR}^{2}$ (ID) \\ Mine GAYAF $^{1}$ (ID) \\ Melih BÜYÜKȘiRIN ${ }^{\mathbf{1}}$ (ID) \\ Gülru POLAT ${ }^{1}$ (ID) \\ Gülistan KARADENIZ ${ }^{1}$ (ID) \\ Aylin ALPÖZEN ${ }^{1}$ (ID) \\ Aysu AYRANCI ${ }^{1}$ (ID) \\ Fatma ÜÇSULAR ${ }^{1}$ (ID) \\ Zeynep \\ SEYMENOĞLU ${ }^{1}$ (ID) \\ Özgür BATUM ${ }^{1}$ (ID)
}

Cite this article as: Güldaval F, Anar C, Gayaf M, Büyükșirin $M$, Polat G, Karadeniz $G$, et al. Clinical presentation of health care workers with symptoms of coronavirus disease 2019 at the Izmir tertiary education hospital, during an early phase of the pandemic. Tuberk Toraks 2020;68(3):218-226.

\section{Yazışma Adresi (Address for Correspondence)}

Dr. Ceyda ANAR

İzmir Dr. Suat Seren,

Gögüs Hastalıkları ve Cerrahisi Eğitim

ve Araştırma Hastanesi,

Göğüs Hastalıkları Anabilim Dalı,

IZMIR - TÜRKIYE

e-mail: drceydaanar@hotmail.com

OCopyright 2020 by Tuberculosis and Thorax.

Available on-line at www.tuberktoraks.org.com
${ }^{1}$ Clinic of Chest Diseases, Izmir Dr. Suat Seren Chest Diseases and Thoracic Surgery Training and Research Hospital, Izmir, Turkey

${ }^{1}$ Izmir Dr. Suat Seren Gögüs Hastalıkları ve Cerrahisi Ĕgitim ve Araştırma Hastanesi, Göğüs Hastalıkları Kliniği, İzmir, Türkiye

${ }^{2}$ Department of Chest Diseases, Faculty of Medicine, Izmir Katip Celebi University, Izmir, Turkey

2 Izmir Katip Çelebi Üniversitesi, Göğüs Hastalıkları Anabilim Dalı, izmir, Türkiye

\section{ABSTRACT \\ Clinical presentation of health care workers with symptoms of coronavirus disease 2019 at the İzmir tertiary education hospital, during an early phase of the pandemic \\ Introduction: The aim of this study is to investigate and report on the data regarding the clinical characteristics and outcomes of healthcare workers with COVID-19 at tertiary education hospitals from Turkey.}

Materials and Methods: This was a single center, retrospective, descriptive and observational study using cross-sectional data, which were collected from confirmed COVID-19 patients at a tertiary education hospital. Patients' demographic and clinical characteristics, mortality rates, and the factors associated with hospitalization were analyzed.

Results: By May 15, 2020, 480 patients were diagnosed with COVID-19 in our hospital where $49(10.2 \%)$ of whom were HCWs. The mean age was $40.0 \pm$ 8.45 ( $75.5 \%$ female). The most common symptoms were cough $(32.7 \%)$, fever $(30.6 \%)$, and myalgia $(14.3 \%)$. Comorbidities were present in $32.7 \%$ of the patients. Most of the HCWs were nurses (53.1\%) and physicians $(18.4 \%)$, and the remaining $14(28.6 \%)$ were cleaning and administrative staff. The severity of the disease was mild in $65.3 \%$ and severe in $34.7 \%$ HCWs. Leukocyte, neutrophil, lymphocyte and platelet values were statistically lower in hospitalized patients. There was a statistically significant relationship between the presence of infiltration on the chest $X$-ray, and the patient's symptoms with the severity of the disease (respectively $p=0.002$ and 0.009).

Conclusion: In conclusion, the frequency of COVID-19 in healthcare workers is high. The study presents the characteristics of HCWs infected with coronavirus from a single center in Turkey.

Key words: Coronavirus; health care workers (HCWs); symptoms 


\section{ÖZ}

Pandeminin erken evresinde İzmir'de bir 3. basamak eğitim araştırma hastanesinde koronavirüs hastalığı belirtileri olan sağlık çalışanlarının klinik durumu

Giriş: Pandeminin erken evresinde İzmir'de bir 3. basamak eğitim araştırma hastanesinde COVID-19'lu Sağlık çalışanlarının klinik özelliklerini ve sonuçları hakkındaki verileri araştırmak ve raporlamaktır.

Materyal ve Metod: Bu, doğrulanmış COVID-19 hastalarından bir 3. basamak eğitim araştırma hastanesinden toplanan kesitsel veriler kullanılarak yapılan tek merkezli, retrospektif, tanımlayıcı, gözlemsel bir çalışmadır. Hastaların demografik ve klinik özellikleri, mortalite oranları ve hastaneye yatışla ilişkili faktörleri analiz edildi.

Bulgular: Hastanemizde 15 Mayıs 2020 itibariyle 49'u (\% 10.2) sağılk çalışanı olan 480 hastaya COVID-19 teşhisi kondu. Ortalama yaş $40.0 \pm 8.45$ (\%75.5 kadın) idi. En sık görülen semptomlar öksürük (\%32.7), ateş \%30.6), miyalji (\% 14.3) idi. Hastaların\%32.7'sinde ek hastalık mevcuttu. Bu sağlık çalışanlarının çoğunu hemşireler (\%53.1) ve doktorlar (\% 18.4) oluştururken geri kalanın 14'ü (\%28.6) temizlik personeli ve idari personeldi. Nötrofil, lenfosit ve trombosit değerleri hastanede yatan hastalarda istatistiksel olarak daha düşüktü. Akciğer grafisinde infiltrasyon varlığı ile hastanın semptomu ve hastalığın şiddeti arasında istatistiksel olarak anlamlı bir ilişki vardı (sırasıyla $p=0.002$ ve 0.009).

Sonuç: Sağlık çalışanlarında COViD-19 sıklığı yüksektir. Türkiye'de tek bir merkezden koronavirüs bulaşmış sağlık çalışanlarının özelliklerini sunuyoruz.

Anahtar kelimeler: Coronavirüs; sağlık çalışanları; semptomlar

\section{INTRODUCTION}

The pneumonia epidemic caused by severe acute respiratory syndrome coronavirus 2 (SARS-Cov-2) originating from the Chinese city of Wuhan continues as a high level of concern in the world. Person-toperson transmission has been confirmed (1-3). On January 30, 2020, the World Health Organization declared a public health emergency of international concern (4). The first case was detected in Turkey on 11 March. Later, the number of cases increased, as it also did so across the world.

Unlike severe acute respiratory syndrome (SARS) or Middle Eastern Respiratory Syndrome, COVID-19 is less virulent, with a lower mortality rate $(5,6)$. Nevertheless, low virulence and longer incubation periods resulted in a significant number of asymptomatic carriers (7). These patients might not take adequate precautions and thus could become a source of transmission (1). Second generation cases, spread by patients in the incubation period and asymptomatic carriers, have already been reported, and these cases appear to have included health care workers (HCWs) (8). Asymptomatic transmission could further increase the risk of super-spreading in hospitals (9).

The Dr. Suat Seren Chest Diseases and Research Hospital is a tertiary hospital in Izmir, Turkey. During the epidemic outbreak, the hospital accommodated COVID-19 in patients for the treatment. Frontline HCWs could be at high risk of infection because of close contact with these patients. SARS-CoV-2 infection hospital outbreaks occurred in the early stages of the outbreak when the disease was not recognized, and before quarantine measures were implemented. In the early stages of the outbreak, the differential diagnosis between COVID-19 and infections caused by other pathogens is not well known. Therefore, it is even more difficult to take appropriate preventive measures to identify SARS-CoV2 infected patients and prevent hospital infection. While quarantine measures were taken in the early stages of the pandemic, some of the hospital services were reserved for COVID-19 quarantine services, whereas others were reserved as non-COVID-19 services, where only patients with chest diseases were treated. While these precautions were taken in the early stages of the pandemic, COVID-19 diagnoses were obtained in some of the chest disease inpatients in the nonCOVID-19 services, as well as in the healthcare professionals working in those services. Moreover, HCWs with infection could cause secondary transmission among patients, family members, and the community. Therefore, it is important to investigate the infection risk of HCWs and the clinical characteristics of affected cases.

The aim of this study is to investigate and report the data on the clinical characteristics and outcomes of healthcare workers with COVID-19 in a tertiary education hospital from Turkey.

\section{MATERIALS and METHODS}

\section{Study Population}

We retrospectively investigated $49 \mathrm{HCWs}$ with COVID-19 at Dr. Suat Seren Chest Diseases and Surgery Training Hospital from March 12 to May 15, 
2020. Exposure, epidemiologic, and demographic information were retrospectively collected by a structured questionnaire, and the clinical, laboratory, and radiologic information were collected from electronic medical records. The study was approved by the Dr. Suat Seren Chest Diseases and Surgery Training Hospital research ethics committee.

The study population was divided into three groups; high, medium and low risk exposure according to exposure risk. Chest diseases, infection and surgical departments, as well as intensive care services, which are the departments where all interventional medical and surgical procedures that form an aerosol, were defined as high-risk exposure. All other areas were identified as medium and low-risk exposure areas. All cases were diagnosed by PCR, and coronavirus nucleic acid was detected by the RT-PCR technique.

Patients were separated into three groups according to the clinical presentation based on the definitions in the "COVID-19 Diagnosis and Treatment Guide" published by the Turkish Ministry of Health. Mild illness presents with features such as fever, muscle/joint pain, cough, sore throat, and nasal congestion, with or without mild pneumonia together with a respiratory rate $<30 / \mathrm{min}$ and an $\mathrm{O}_{2}$ saturation above $90 \%$ while breathing room air. Severe illness is defined with widespread findings of pneumonia in chest radiography or computed tomography (CT). Critical illness defines the requirement of the ICU (10).

\section{Statistical Analysis}

The data obtained in the study were entered into the database created in the SPSS (Statistical Package for Social Sciences) 18.0 program and statistical analyzes were conducted. Categorical variables, frequencies, percentages, mean, standard deviation, median, min. and max. values were calculated. Continuous variables were described with medians and interquartile ranges (IQRs). Categorical variables were described as frequency and percentages. Conformity of continuous variables to normal distribution was investigated and it was decided that the conditions for normal distribution compliance could not be met in all variables considering the graphical research. Normality tests and sample diameter, and non-parametric methods were preferred in comparisons. The Mann-Whitney $U$ test, $\chi 2$ test, and Fisher exact test were used according to variable types as appropriate. Binary comparisons of independent groups were used with the Mann-Whitney $U$ test.
Cross tables were prepared in categorical variables, distribution differences of groups were tested with Chi-Square test and Fisher's Exact test methods, and the risk coefficients were calculated. In all statistical comparison tests, the first type of error margin was determined as $\alpha$ : 0.05 and a double-tailed test were used. The difference between the groups was considered statistically significant if the value of " $p$ " was less than 0.05 .

\section{RESULTS}

\section{Demographic Characteristics}

By May 15, 2020, 480 patients were diagnosed with COVID-19 in Dr. Suat Seren Chest Diseases and Surgery Training Hospital, where $49(10.2 \%)$ of whom were HCWs. Overall, 37 (75.5\%) of those $\mathrm{HCW}$ s with infection were women and ages ranged from 23 to 59 years with a median (interquartile range, IQR) of 41. Most of these healthcare workers were nurses $26(53.1 \%)$ and physicians (9) $(18.4 \%)$, and the remaining $14(28.6 \%)$ were cleaning and administrative staff. Of the 222 doctors and 344 nurses who work in our hospital, 26 (7.5\%) nurses and 9 $(4.05 \%)$ doctors were infected with COVID-19. Of the 49 cases, $33(67.3 \%)$ had high-risk contact, 13 (26.5\%) patients had medium and 3 patients $(6.1 \%)$ had low-risk contact. The median (IQR) of weekly work was 40 hours. The demographic characteristics of patients are described in Table 1.

\section{Common Symptoms}

While 36 patients had symptoms, 13 patients had no symptoms. Common symptoms were cough $(32.7 \%)$, fever $(30.6 \%)$, myalgia $(14.3 \%)$, headache $(12.2 \%)$, weakness $(12.2 \%)$, and dyspnea (10.2\%) among the 36 HCWs who have symptoms (Figure 1).

\section{Radiological Features}

The chest radiographs of $27(55.1 \%)$ healthcare workers were normal. Bilateral infiltration was present in 15 (30.6\%) healthcare workers and unilateral infiltration in $5(10.2 \%)$ seen in chest radiographs. Two asymptomatic HCWs did not want to have a chest X-ray. Computed tomography was performed in $47(95.9 \%)$ patients and $22(44.9 \%)$ of them were normal. Examination of the radiological findings showed that the lesions tended to be located more in the peripheral lobes. The most common radiological feature was bilateral ground glass (28.6\%) opacities (Table 2). 
Güldaval F, Anar C, Gayaf M, Büyükşirin M, Polat G, Karadeniz G, et al.

Table 1. Demographic characteristics of healthcare workers in the study

Characteristics

Gender

Female

Male

History of cigarette

Non smoker

Ex-smoker

smoker

Comorbidities

Present

Absent

Hypertension

Diabetes mellitus

Coroner artery disease

Tyroid

Celiac disease

familial Mediterranean fever

Gilbert Syndrome

Asthma

Rheumatic disease

Occupation

Nurse

Doctor

Staff

Contact risk

Low

Middle

High

Severity of illness

Mild

Severe

Hospitalization

Present

Absent

Intensive care unit

Present

Absent

Treatment

Klorokin/Azitro/Oseltemavir

Klorokin/Azitro

Klorokin

Klorokin/Oseltemavir/Moksifloksasin

Klorokin/Oseltemavir

Klorokin/Azitro/Favipavir

Favipavir

No treatment

\section{n}

37

12

18

14

17

28.6

34.7

32.7

67.3

12.2

4.1

2

8.2

2

2

2

4.1

2

53.1

18.4

28.6

14

6.1

26.5

67.3

33

65.3

34.7

34.7

65.3

32

2

1

98

32.7

36.7

10.2

6.1

6.1

2

2

2 


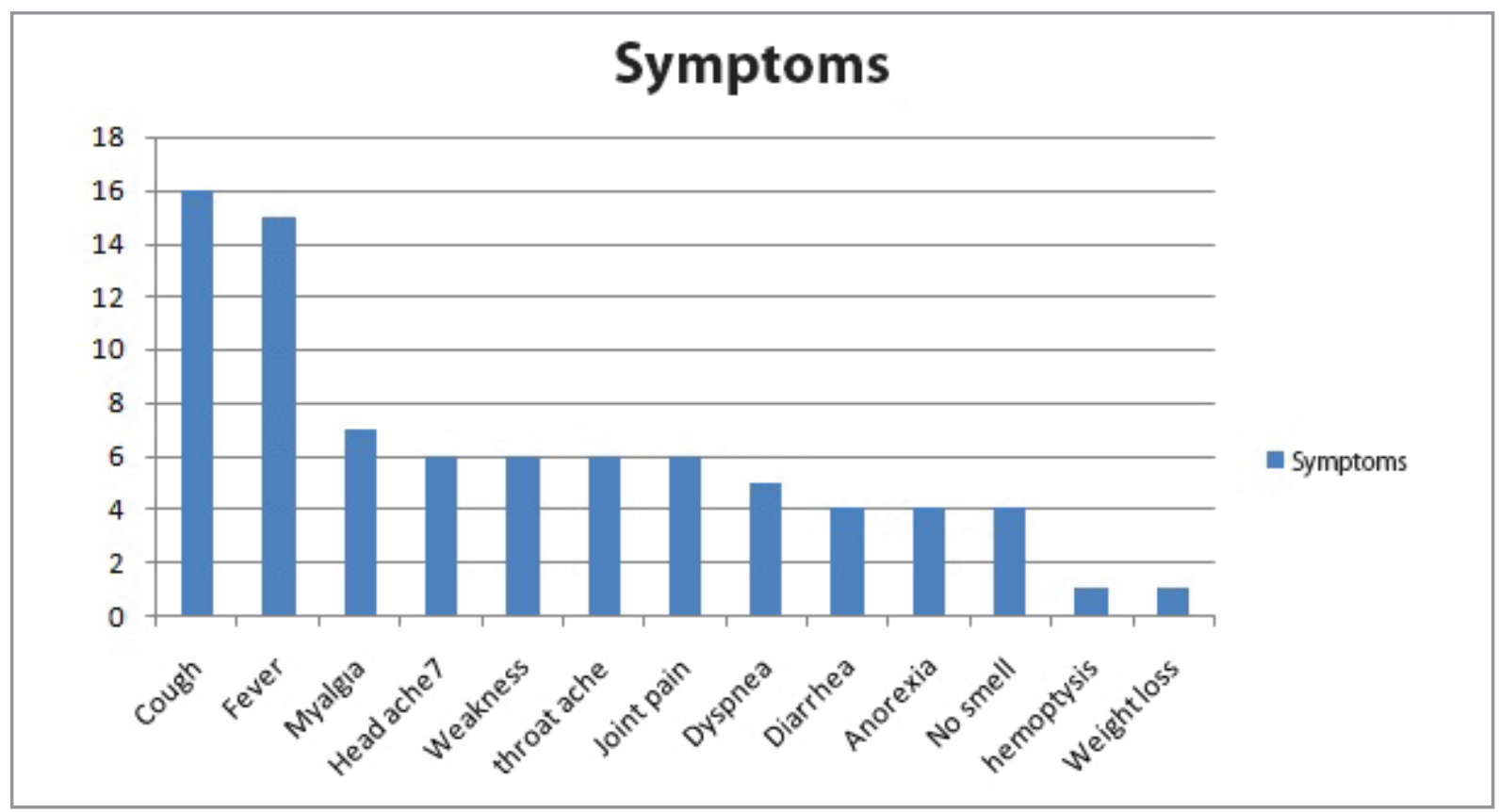

Figure 1. Symptoms of health care workers.

\section{Table 2. Distribution of Radiological Findings}

\begin{tabular}{lcc|} 
Chest Radiograph Findings & $\mathbf{n}$ & $\%$ \\
\hline Normal & 27 & 55.1 \\
Bilateral infiltration & 15 & 30.6 \\
Unilateral infiltration & 5 & 10.2 \\
HRCT findings* & 22 & 44.9 \\
Normal CT findings & 14 & 28.6 \\
Bilateral Ground glass & 5 & 10.2 \\
Unilateral ground glass & 1 & 2 \\
Consolidation & 1 & 2 \\
Reticular infiltration & 2 & 4.1 \\
Nodal & 1 & 2 \\
Bilateral ground glass + consolidation & 1 & 2 \\
Bilateral ground glass + nodal & & 51 \\
Radiological distribution & 25 & 2 \\
Peripheral location & 1 & \\
Central location & & \\
\hline$*$ One person can have more than one finding. & & 2 \\
\hline
\end{tabular}

\section{Factors Associated with Hospitalization and Disease Severity}

Leukocyte, neutrophil, lymphocyte and platelet values were statistically lower in hospitalized patients. In addition, hospitalization rate of patients with infil- tration on chest x-ray was significantly higher than, hospitalization rate of patients with normal chest x-ray. (Table 3).

No relationship was found between disease severity, age, smoking history, gender or additional disease. 
Table 3. Factors related to hospitalization

\begin{tabular}{|c|c|c|c|}
\hline & $\begin{array}{l}\text { Hospitalized } \\
\text { n: } 17\end{array}$ & $\begin{array}{c}\text { Non-Hospitalized } \\
\text { n: } 32\end{array}$ & p \\
\hline Age, $($ mean \pm SD $)$ & $39.2 \pm 9.8$ & $40.5 \pm 7.7$ & 0.689 \\
\hline \multicolumn{4}{|l|}{ Gender } \\
\hline Male & $4(23.5)$ & $8(25)$ & \multirow[t]{2}{*}{$>0.999$} \\
\hline Female & $13(76.5)$ & $24(75)$ & \\
\hline \multicolumn{4}{|l|}{ History of cigarette } \\
\hline Smoker & $5(29.4)$ & $12(37.5)$ & \multirow[t]{3}{*}{0.837} \\
\hline Ex-smoker & $5(29.4)$ & $9(28.1)$ & \\
\hline Nonsmoker & $7(41.2)$ & $11(34.4)$ & \\
\hline \multicolumn{4}{|l|}{ Additional diseases } \\
\hline Present & $4(23.5)$ & $12(37.5)$ & \multirow[t]{2}{*}{0.501} \\
\hline Absent & $13(76.5)$ & $20(62.5)$ & \\
\hline \multicolumn{4}{|l|}{ Symptom } \\
\hline Present & $17(100)$ & $19(59.4)$ & \multirow[t]{2}{*}{0.002} \\
\hline Absent & $0(0)$ & $13(40.6)$ & \\
\hline \multicolumn{4}{|l|}{ Chest radiograph } \\
\hline Infiltration & $11(64.7)$ & $9(30)$ & \multirow[t]{2}{*}{0.045} \\
\hline Normal & $6(35.3)$ & $21(70)$ & \\
\hline \multicolumn{4}{|l|}{ Computed tomography } \\
\hline Bilateral localization & $9(60.0)$ & $8(72.7)$ & \multirow[t]{2}{*}{0.683} \\
\hline Unilateral localization & $6(40.0)$ & $3(27.3)$ & \\
\hline Working hour (weekly) (mean \pm SD) & $41.6 \pm 13.5$ & $38.0 \pm 15.8$ & 0.386 \\
\hline \multicolumn{4}{|l|}{ Complete blood count, $($ mean \pm SD $)$} \\
\hline WBC & $4850 \pm 1515$ & $8004 \pm 2606.4$ & $<0.001$ \\
\hline Neutrophil & $2778.5 \pm 1217$ & $4904 \pm 2441$ & 0.001 \\
\hline lymphocyte & $1500 \pm 620$ & $2248 \pm 728$ & 0.009 \\
\hline Platelets & $221.0 \pm 59.3$ & $305.1 \pm 52.7$ & $<0.001$ \\
\hline NLR & $2.0 \pm 1.1$ & $2.4 \pm 1.6$ & 0.459 \\
\hline CRP & $4.8 \pm 7.9$ & & 0.065 \\
\hline
\end{tabular}

There was a statistically significant relationship between the presence of infiltration on the chest X-ray, the patient's symptoms and the severity of the disease (respectively $p=0.002$ and 0.009 ). Leukocyte, neutrophil, lymphocyte and platelet values were statistically lower in patients with severe disease compared to those with mild disease. While there was no statistical difference between $\mathrm{N} / \mathrm{L}$ ratios in hospitalized and non-hospitalized cases, it was found that $\mathrm{N} / \mathrm{L}$ ratios were statistically higher in severe cases (Table 4).

\section{DISCUSSION}

This article is based on a retrospective study presenting the first data on COVID-19 health care workers from Turkey, in a chest hospital in Izmir during an early phase of the pandemic.
The study included positive cases confirmed with the RT-PCR method. A particular focus was given to investigate the HCWs' characteristics. The mean age of the HCWs was $40.0 \pm 8.4$, and $75.5 \%$ were female. The most common symptoms on admission were cough $(32.7 \%)$ and $(30.6 \%)$ fever. Comorbidities were present in $32.7 \%$ of the HCWs. The comorbidities with the highest frequency were hypertension $(12.2 \%, \mathrm{n}=6)$ and diabetes $(4.1 \%, \mathrm{n}=2)$. In a retrospective study, a total of 54 cases of SARS-Cov-2 infected medical staff from Tongji Hospital between 7 January and 11 February 2020 were analyzed (11). Most of them were from other clinical departments $(72.2 \%)$ rather than emergency department $(3.7 \%)$ or medical technology departments $(18.5 \%)$. Among the 54 patients with COVID-19, the distribution of age had a significant difference between non-severe type and severe/critical 
Table 4. Factors associated with diseases severity

\begin{tabular}{|c|c|c|c|}
\hline & $\begin{array}{l}\text { Mild COVID-19 } \\
\text { n: } 32\end{array}$ & $\begin{array}{c}\text { Severe COVID-19 } \\
\text { n: } 17\end{array}$ & $\mathbf{p}$ \\
\hline Age, $($ mean $\pm \mathrm{SD})$ & $39.2 \pm 9.8$ & $40.5 \pm 7.7$ & 0.689 \\
\hline \multicolumn{4}{|l|}{ Gender } \\
\hline Male & $8(25 \%)$ & $4(75 \%)$ & \multirow[t]{2}{*}{$>0.999$} \\
\hline Female & $24(75 \%)$ & $13(76.5 \%)$ & \\
\hline \multicolumn{4}{|l|}{ History of cigarette } \\
\hline Smoker & $11(34.4 \%)$ & $6(35.3 \%)$ & \multirow[t]{2}{*}{$>0.999$} \\
\hline Ex-smoker/nonsmoker & $21(65.6 \%)$ & $11(64.7 \%)$ & \\
\hline \multicolumn{4}{|l|}{ Additional diseases } \\
\hline Present & $9(28.1 \%)$ & $7(71.9 \%)$ & \multirow[t]{2}{*}{0.544} \\
\hline Absent & $23(41.2 \%)$ & $10(58.8 \%)$ & \\
\hline \multicolumn{4}{|l|}{ Symptoms, n (\%) } \\
\hline Present & $19(59.4 \%)$ & $17(100 \%)$ & \multirow[t]{2}{*}{0.002} \\
\hline Absent & $13(40.6 \%)$ & $0(0 \%)$ & \\
\hline \multicolumn{4}{|l|}{ Chest radiograph, n (\%) } \\
\hline Infiltration(+) & $8(26.7 \%)$ & $12(70.6 \%)$ & \multirow[t]{2}{*}{0.009} \\
\hline Normal & $22(73.3 \%)$ & $5(29.4 \%)$ & \\
\hline Working hours (weekly) & $37 \pm 14$ & $44 \pm 15$ & 0.087 \\
\hline \multicolumn{4}{|c|}{ Complete blood count, (mean \pm SD) } \\
\hline WBC & $7990 \pm 2617$ & $5080 \pm 1826$ & 0.001 \\
\hline Lymphocyte count $\left(10^{3} / \mathrm{uL}\right)$ & $2255 \pm 757$ & $1540 \pm 600$ & 0.007 \\
\hline Neutrophil count & $4840 \pm 2543$ & $3007 \pm 1330$ & 0.010 \\
\hline Platelet & $302 \pm 57$ & $231 \pm 63$ & 0.002 \\
\hline NLR & $2.4 \pm 1.7$ & $16.3 \pm 19.3$ & 0.037 \\
\hline CRP & $3 \pm 5$ & $2 \pm 6$ & 0.959 \\
\hline
\end{tabular}

cases. In our study no difference was found between age and disease severity. The severity of the disease was mild in $65.3 \%$ of the cases, moderate in $26.5 \%$ and $8.2 \%$ of the patients were classified as severe. The most infected HCWs were nurses. Only one healthcare worker required ICU admission. No healthcare worker died. it is important to note there were not sufficient reserves of protective equipment in the hospital for an early phase of pandemic. The protective equipment, such as protective clothing, N95 masks, and goggles are prioritized to first-line medical staff in fever clinics and fever wards, while other staff have only surgical masks in an early phase of pandemic. Despite this, it was seen more frequently in medical staff. This may be because nurses enter patient rooms more often for treatment. According to the article by Wang, et al (8) on 7 February 2020, among the 138 cases admitted by Wuhan Zhongnan Hospital, 17 cases (12.3\%) were hospitalized for reasons other than pneumonia, such as conditions that requires surgery and tumors, including 7 cases in the surgery department, 5 cases in the inter- nal medicine department, and 5 cases in the oncology department. These cases may even have been infected during hospitalization. As patients in hospital frequently contact inpatient caregivers and visitors that frequently go in and out of hospital and are at high risk of getting infected, which exacerbates infections of medical staff not in direct contact with the known infected patients. Also, the infected medical staff may be asymptomatic but infectious, which may lead to clustered infection in a department (12).

The COVID-19 pandemic epidemiology varies between countries. Possible reasons for this variation include demographic and socio-cultural structure; transportation at national and international levels; capacity, ease of access and versatility of health care systems; as well as the nature, extent, and timing of the pandemic control strategies directed by the government. The epidemiological data is required to guide the situational awareness and intervention strategies as long as the pandemic remains. Many factors influence the nosoco- 
mial spread of infectious diseases, and HCWs are the initial point of contact with patients in both acute and long-term health care settings. In a study on HCWs who perform a high risk procedures (HRP) have a greater risk of respiratory infections than those who do not perform a HRP (13). In our study, there were no high-risk procedures (such as suctioning, intubation and broncoscopies) other than the doctors. However, in our study it is thought that the contamination is mostly related to hand hygiene and contact. Especially in the early period of the pandemic, the lack of personnel protective equipment and the complete control of the contamination during the separation of the COVID and non-COVID services caused the healthcare workers to become infected in our hospital.

Contact transmission is one of the main routes of the SARS-CoV-2. Transmission from patients to HCWs usually follows contamination of the $\mathrm{HCWs}^{\prime}$ hands after touching either patients or fomites, whereas hand hygiene is considered the most important prevention measure for healthcare-associated infections. In a study, Ran et al found that the relative risks and their $95 \%$ confidence intervals of unqualified hand-washing, suboptimal hand hygiene before and after contact with patients, and improper personnel protective equipment were $2.64(95 \% \mathrm{Cl}=1.04-6.71, \mathrm{p}<0.05)$, $3.10(95 \% \mathrm{Cl}=1.43-6.73, \mathrm{p}<0.01), 2.43(95 \% \mathrm{Cl}=$ $1.34-4.39, \mathrm{p}<0.01)$, and $2.82(95 \% \mathrm{Cl}=1.11-7.18, \mathrm{p}<$ $0.05)$, respectively (14). As is commonly known, washing hands can significantly reduce residual viruses and bacteria on your hands. Among healthcare professionals, nurses were the most infected. We thought that the reason for this may be related to the fact that the nurses entered the rooms of inpatients more than other staff to give treatment and control fever.

HCWs in China are generally working long hours, with an average work week exceeding 54 hours (15). Moderate work hour benefits the health and safety of HCWs, while prolonged work (> 10 hours/day) would possibly increase the risk of respiratory infections $(16,17)$. Consideration of duty hour restrictions (less than 10 hours/day) should be considered, depending on the medical staff's specific role. In our study, the weekly working hours of the HCWs were $39.3 \pm 15.0$ hours. There was no difference between working hours and hospitalization in healthcare workers in our study.

The spectrum of disease severity and its causes are among the issues that aroused the greatest curiosity. In the literature, the spectrum of symptomatic infections ranges from mild to critical, and most of these infec- tions are not severe. Liu et al. reported that in addition to personal factors, viral load is an important factor in different clinical courses in cases of COVID-19 (18). In light of these findings, arrangements concerning the protection of HCWs dealing with a large number of cases are of crucial importance. In our study, no mortality was observed in this group. There was a statistically significant relationship between the presence of infiltration and the patient's symptom on the chest X-ray and the severity of the disease (respectively $p=0.002$ and 0.009). Leukocyte, neutrophil, lymphocyte and platelet values were statistically lower in patients with severe disease severity compared to those with mild disease severity. In addition, the $\mathrm{N} / \mathrm{L}$ ratio was found to be higher in patients with severe disease. In a recent study the dynamic changes of NLR were analyzed. It was found that both the initial and the peak values had a good correlation with the infection markers. Therefore, it could be used as the basis to assess the severity of infection. The initial NLR had a lower AUC compared to the peak NLR, suggesting the peak value is a better predictive marker for death outcome (19). In another study the most common laboratory abnormalities were depressed total lymphocytes, prolonged prothrombin time, and elevated lactate dehydrogenase (8).

There are some limitations to our study. Our study was conducted in a single center from Turkey, so the results, particularly around frequency of performing high-risk procedures, may not be generalizable to different HCW populations in other contexts. There are variations in infection control practices from hospital to hospital, even within Turkey. However, the quantification of risk for HCWs who perform HRPs has implications for HCWs everywhere. In addition, the low number of patients is another limitation.

In conclusion, we present the characteristics of healthcare workers infected with coronavirus from a single center in Turkey. SARS-CoV-2 is highly contagious. In this study, we showed that, personal protective equipment and frequency of contact time are important. Hospitalized patients and HCWS in the epidemic are at high risk of infection. Protecting HCWs is an important component of public health measures for addressing the COVID-19 epidemic.

\section{ACKNOWLEDGEMENTS}

The authors thank all COVID-19 Working Group members at University of Health Sciences Turkey, Dr. Suat Seren Chest Diseases and Surgery, Medical Practice and Research Center: 
Berrin Akkol, Nimet Aksel, Gülsüm Arı, Sena Ataman, Çağrı Atasoy, Günseli Balcı, Mualla Elif Bayındır, Aylin Bayram, Eda Bayramiç, Can Biçmen, Semra Bilaçeroğlu, Seda Bilgen, Emel Cireli, Melis Çaktu, Kadri Çırak, Pınar Çimen, Hasan Demir, Özlem Ediboğlu, Ece Elburus, İsmail Erikçi, Sinem Ermin, Mücahit Fidan, Mine Gayaf, Gamze Göker, Mutlu Onur Güçsav, Burçin Hakoğlu, Lütfü Can Hepduman, Osman Hilmioğlu, Fatmanur Kazankaya, Merve Keskin, Cenk Kıraklı, Ali Korkmaz, Berna Kömürcüoğlu, Nil Kuranoğlu, Aydan Mertoğlu, Zeynep Öndeş, Hilal Özdemir, Serir Özkan, Bilge Salık, Hülya Şahin, Yosun Şan, Güneş Şenol, İmren Taşkıran, Dursun Tatar, Zühre Sarp Taymaz, Serpil Tekgül, ìhsan Topaloğlu, Fevziye Tuksavul, Betül Tunçel, Merve Türk, Damla Serçe Unat, Özgür Uslu, Yelda Varol, Enver Yalnız, Özlem Yalnız, Illkin Yetişkin, Celalettin Yılmaz, Ufuk Yılmaz, Sami Deniz, Nisel Yılmaz.

Ethics Committee Approval: The approval for this study was obtained from Dr. Suat Seren Chest Diseases and Surgery Training Hospital Research Ethics Committee (Decision no: 11 Date: 15.05.2020).

\section{CONFLICT of INTEREST}

There is no conflict of interest related to this study.

\section{AUTHORSHIP CONTRIBUTIONS}

Concept/Design: All of authors

Analysis/Interpretation: All of authors

Data Acquisition: All of authors

Writting: FG, CA, MG, GP, GK, AA

Critical Revision: All of authors

Final Approval: All of authors

\section{REFERENCES}

1. Li Q, Guan X, Wu P, Whang X, Zhou L, Tong Y et al. Early transmission dynamics in Wuhan, China, of novel coronavirus-infected pneumonia. N Engl J Med 2020; 382(13): 1199-207.

2. Zhou P, Yang XL, Wang XG, Hu B, Zhang L, Zhang $W$, et al. A pneumonia outbreak associated with a new coronavirus of probable batorigin. Nature 2020; 579(7798): 270-3.

3. Phan LT, Nguyen TV, Luong QC, Nguyen TV, Nguyen HT, Le $H Q$, et al. Importation and human-to-human transmission of a novel coronavirus in Vietnam. $N$ Engl J Med 2020; 382(9): 872-4.

4. Wu C, Chen X, Cai Y, Xia J, Zhou X, Xu S, et al. Risk factors associated with acute respiratory distress syndrome and death in patientswith coronavirus disease 2019 pneumonia in Wuhan, China. JAMA Intern Med 2020.
5. Chen J. Pathogenicity and transmissibility of 2019-nCoV-A quick overview and comparison with other emerging viruses. Microbes Infect 2020; 22(2): 69-71.

6. Mahase E. Coronavirus COVID-19 has killed more people than SARS and MERS combined, despite lower casefatality rate. $B$ MJ 2020; 368: $m 641$.

7. Zou L, Ruan F, Huang M, Liang L, Huang H, Hong Z, et al. SARS-CoV-2 viral load in upper respiratory specimens of infected patients. N Engl J Med 2020; 382(12): 1177-9.

8. Wang D, Hu B, Hu C, Zhu F, Liu X, Zang J, et al. Clinical characteristics of 138 hospitalized patients with 2019 novel coronavirus-infected pneumonia in Wuhan, China. JAMA 2020; 323(11): 1061-9.

9. Cho SY, Kang JM, Ha YE, Park GF, Lee $J Y, K o J H$, et al. MERS-CoV outbreak following a single patient exposure in an emergency roomin South Korea: an epidemiological outbreak study. Lancet 2016; 388(10048): 994-1001.

10. T. C. Ministry Of Health General Directorate Of Public Health, Covid-19 (Sars-Cov2 Infection) Directory, Coronavirus Scientific Advisory Board, Turkey. 2020.

11. Jiaojiao $C$, Yang $N$, Wei $Y$, Yue $H$, Zhang $F$, Zhao J, et al. Clinical characteristics of 54 medical staff with COVID-19: A retrospective study in a single center in Wuhan, China I Med Virol 2020: 10.1002/jmv.25793

12. Chan JFW, Yuan S, Kok KH, Chu H, Yang J, Xing F, et al. A familial cluster of pneumonia associated with the 2019 novel coronavirus indicating person-to-person transmission: a study of a family cluster. Lancet 2020; 395(10223): 514-23.

13. Macintyre $C R$, Seale1 $H$, Yang $P$, Zhang $Y$, Shi $W$, Almatroudi A, et al. Pang.Quantifying the risk of respiratory infection in healthcare workers performing high-risk procedures. Epidemiol Infect 2014; 142: 1802-8.

14. Ran I, Chen X, Wang Y, Wu W, Zhang L, Tan X. Risk Factors of Healthcare Workers with Corona Virus Disease 2019: A Retrospective Cohort Study in a Designated Hospital of Wuhan in China, 2020.

15. Wen J, Hao T, Hu X. Doctor's Workload in China: A Statusquo Study. Chin J Evid-based Med 2015; 15(2): 133-6.

16. Li D, Wu S. Analysis on the health status and influencing factors of medical workers in a city of Fujian province. The Medical Forum 2016; 20(14): 1893-5.

17. Weaver MD, Landrigan CP, Sullivan JP, O'Brien CS, Qadri $S$, Viyaran $N$, et al. The association between resident physician work hour regulations and physician safety and health. Am J Med 2020; 133(7): e343-e354

18. Liu, Y. Yan LM, Wan L, Xiang TX, Le A, Liu JM, et al., Viral dynamics in mild and severe cases of COVID-19. Lancet Infect Dis 2020; 20(6): 656-7.

19. Wenjing $Y$, Xiopan $L$, Xing L, Chen J, Min H, Zhang D, et al. Dynamic changes of D-dimer and neutrophil-lymphocyte count ratio as prognostic biomarkers in COVID-19. Respir Res 2020; 21: 169 . 